\title{
Biopsychosocial Determinants of Multi Drug Resistant Tuberculosis in Surakarta
}

\author{
Lina Alfiyani'), Setyo Sri Rahardjo²), Bhisma Murti') \\ 1)Masters Program in Public Health, Sebelas Maret University \\ 2)Faculty of Medicine, Sebelas Maret University
}

\begin{abstract}
Background: Tuberculosis is an infectious disease that poses serious threat to population health worldwide. Tuberculosis control enterprise becomes more complicated due to increasing number of Multi Drug Resistant Tuberkulosis (MDR-TB) cases. Globally there are approximately 580,000 cases of MDR-TB, with only 125,000 cases (20\%) resolved. Indonesia ranks tenth in the world by the number of MDR-TB cases after Angola, Azerbaijan, Bangladesh, Belarus, Cina, Korea, Kongo, Etiopia, and India. This study aimed to analyzed the bio-psychosocial determinants of MDR-TB in Surakarta.

Subjects and Method: This was an analytic observational study with case control design. The study was conducted in Dr. Moewardi Hospital and BBKPM, Surakarta, from September to November 2017. A sample consisting of 76 MDR-TB patients and 228 non MDR-TB patients were selected for this study by fixed disease sampling. The dependent variable was MDR-TB. The independent variables were age, drug-taking adherence, depression, comorbidity, drug side-effect, drug-taking supervisor, and family income. The data were collected using a set of questionnaire and analyzed by path analysis.

Results: MDR-TB was affected by lack of drug-taking adherence $(b=-1.7 ; 95 \% \mathrm{CI}=\mathbf{- 2 . 2 3}$ to -1.07 ; $\mathrm{p}=0.001)$ and comorbidity $(\mathrm{b}=1.5 ; 95 \% \mathrm{CI}=0.76$ to $2.30 ; \mathrm{p}=0.001)$. Drug-taking adherence was affected by depression $(b=-1.7 ; 95 \% \mathrm{CI}=-2.60$ to $-0.79 ; \mathrm{p}=0.001)$, drug side effect $(\mathrm{b}=-1.5 ; \mathrm{CI}$ $95 \%=-2.10$ to $-0.86 ; \mathrm{p}=0.001)$, and drug-taking supervisor $(\mathrm{b}=2.5 ; 95 \% \mathrm{CI}=1.84$ to 3.06; $\mathrm{p}=0.001)$. Comorbidity was affected by age $(\mathrm{b}=0.86 ; 95 \% \mathrm{CI}=0.12$ to $1.61 ; \mathrm{p}=0.022)$.

Conclusion: MDR-TB is directly affected by lack of drug-taking adherence and comorbidity. MDR-TB is indirectly affected by drug-taking supervisor, depression, and drug side effect.
\end{abstract}

Keyword: bio-psychosocial determinants, MDR-TB

\section{Correspondence:}

Lina Alfiyani. Masters Program in Public Health, Sebelas Maret University, Jl. Ir. Sutami 36 A, Surakarta, Central Java. Email: linabbt@gmail.com.

\section{BACKGROUND}

Tuberculosis (TB) is one of the infectious diseases as the most leading to death in cases of tuberculosis with HIV comorbidities (Falzon et al., 2013). Tuberculosis is among the top 10 diseases causing death in the world with 1.4 million deaths annually (Petruccioli et al., 2016). The highest case of tuberculosis in 2015 comes from Southeast Asia (45.6\%) of the world's population, and Indonesia ranks 2 out of 11 countries after India (23\%) with the percentage of $10 \%$, namely 1020 cases per
1000 population with the highest burden of tuberculosis (WHO, 2016a).

Another fundamental issue other than the case of death is the economic problem. The decrease in productivity in patients becomes a problem that needs to be considered. The high cases of tuberculosis and the emergence of economic problems are becoming public health problems in the world especially in developing countries including Indonesia (Sulistiyani et al., 2015). 
Journal of Epidemiology and Public Health (2017), 2(3): 255-266

https://doi.org/10.26911/jepublichealth.2017.02.03.07

High tuberculosis cases are difficult to detect and reduce, it is due to the medical and non-medical problems, which include medical problems such as the nature of tuberculosis as a chronic disease, inadequate use of anti-tuberculosis (OAT) drugs, immunodepression, age $\geq 35$ years, diabetes mellitus and the occurrence of ESO, whereas non-medical problems include poverty, low education, low support of PMO and delayed diagnosis (Zhang et al., 2016). Amita and Pratima (2008) explain that genetic factors, incomplid treatment and treatment adherence, microbiology, clinical factors, HIV / AIDS, programs and germs affect MDR-TB (Hirpa et al., 2013).

WHO recommends Isoniazid and rifampicin as effective drugs for the firstline treatment. Therefore, resistance to both drugs has become a serious threat (Mekonnen et al., 2015). WHO (2017) mentions in the handling of MDR-TB sustained crisis detection. Globally, 580,000 cases of tuberculosis have MDR$\mathrm{TB}$, with 125,000 (20\%) cases were resolved. Indonesia was one of the worst crisis in the world and ranked tenth in the world (WHO, 2016b). 45\% of the cases of detectable and potentiated MDR-TB needed to improve tuberculosis detection and early identification of MDR-TB as key to solve the problem (Prosser et al., 2016).

Data on MDR-TB cases in Indonesia in 2015 display that there were 15.380 cases, 1,860 confirmed cases and 1,566 cases treated. 17 provinces in Indonesia have success rate of tuberculosis treatment $<85 \%$, one of them is Central Java Province (Ministry of Health, 2016). The case of tuberculosis in Surakarta was in the third highest in Central Java Province with case notification rate (CNR) in 2016 of 85 per 100,000 population (Central Java Provincial Health Office, 2016). Based on preliminary study, in 2015, MDR-TB clinic visit reached 1839. In 2016, it reached 1793 and in 2017 it reached 1466 visit (period of January-May). The number of visits in 2017 was likely to increase again until the December period. In addition to the preliminary study results in BBKPM Surakarta, the data about treatment for 189 patients were found out.

WHO recommends Directly Observed Treatment Shortcourse (DOTS) strategy as an effort to manage MDR-TB able to give hope for the success of MDR-TB case treatment (Abubakar et al., 2013). On time diagnosis of MDR-TB, particularly among new tuberculosis cases, is important to facilitate appropriate treatment, thus preventing the emergence of advanced drug resistance and its spread in the population (Atre, 2015).

The high prevalence of MDR-TB indicates that the problem is an urgent that must be resolved by using an approach model capable of assessing various factors, either directly or indirectly. This study used a biopsychosocial model approach to assess the determinants based on causation and risk factors for MDR-TB both biologically, psychologically and socially.

Based on the background, the author was interested to analyze Biopsychosocial Determinants of Multi Drug Resistant Tuberculosis in Surakarta.

SUBJECTS AND METHOD

\section{Study design}

This was a case control study. The study was conducted in Dr. Moewardi hospital and BBKPM Surakarta, from September to November 2017.

\section{Population and sample}

The target population was all tuberculosis and MDR-TB patients. The case population was MDR-TB patients in Dr. Moewardi hospital. While the control population was tuberculosis patients in BBKPM Surakarta. 
The sampling technique was fixed disease sampling with a large sample of 304 research subjects using a ratio of 1: 3 . The number of case samples was $76 \mathrm{MDR}-\mathrm{TB}$ patients and the control samples were 228 tuberculosis patients.

The inclusion criteria were subjects aged $\geq 15$ years old and able to fill the questionnaire well. While the exclusion criteria of patients were those who experience psychiatric disorders.

\section{Study variables}

The independent variables were family income, depression, drug side effects, drug taking advisor, adherence, age, comorbidity and the dependent variable was MDR-TB.

\section{Operational definition of variables} MDR-TB was defined as tuberculosis patients diagnosed with MDR-TB because Mycobacterium tuberculosis is resistant to two first-line anti-tuberculosis drugs namely rifampicin and isoniazid, and the measurement tool is X-pert MTB / RIF measurements in medical records. The measurement scale was categorical, coded o for no MDR TB and 1 for MDR TB.

Drug side effect was defined as the reaction of drug as a result of the treatment of tuberculosis. The data were collected by questionnaire. The measurement scale was categorical, coded o for no drug side effect and 1 for drug side effect.

The drug taking advisor support was defined a person who is in charge of ensuring regularity or medication adherence during the patient's treatment period. The data were collected by questionnaire. The measurement scale was categorical, coded o for weak support and 1 for strong support.

Depression was defined an emotional disturbance in patients where patients experience panic, stress, irritability, and fear. The data were collected by questionnaire. The measurement scale was conti- nuous, but for the purpose of data analysis, it was transformed into dichotomous, coded o for low stress and 1 for high stress.

Drug taking adherence was defined as a condition that describes patient obedience in taking the appropriate medications based on health personnel instruction. The data were collected by questionnaire. The measurement scale was continuous, but for the purpose data analysis, transformed into dichotomous, coded o for drug taking irregularly and 1 for drug taking regularly.

Family income was defined as the average income during the last 6 months as a result of the economic process or cumulative economic resources of the whole family members (husband, wife, and children). The data were collected by questionnaire. The measurement scale was continuous, but for the purpose data analysis, transformed into dichotomous, coded $\mathrm{o}$ for low family income and 1 for high family income.

Age was defined as the age of the subjects from the birth to the time the study was conducted. The data were collected by questionnaire. The measurement scale was continuous, but for the purpose data analysis, transformed into dichotomous, coded $\mathrm{o}$ for younger age and 1 for older age.

Comorbidity was defined as the presence of one or more other diseases that accompanied tuberculosis. The data were collected by questionnaire. The measurement scale was categorical, coded o for without co-morbidity and 1 for with comorbidity.

\section{Data analysis}

The data analysis of the study used path analysis to determine the magnitude of the influence of variables, either the directly or indirect influences. The pathway analysis steps are model specification, model 
Journal of Epidemiology and Public Health (2017), 2(3): 255-266

https://doi.org/10.26911/jepublichealth.2017.02.03.07

identification, model conformity, parameter estimation and model respesification.

\section{Research Ethics}

The research ethical clearance was granted from the Research Ethics Committee at Dr. Moewardi Hospital, Surakarta, Central Java, Indonesia. Research ethics included issues such as informed consent, anonymity, confidentiality, and ethical clearance.

\section{RESULTS \\ 1. Sample Characteristics \\ Table 1 shows the sample characteristics. As many as 137 study subjects (85.1\%) were smoker.}

The characteristics of subjects in relation to alcohol habit, in the case group, almost all subjects did not have a habit of alcohol (58 subjects/71.1\%). This is similar to the control group with 195 subjects (85.5\%).

The last characteristic is related to the tuberculosis contact. Most of the subjects did not know about tuberculosis contacts (58 subjects $/ 76.3 \%)$ in the case group. Then, in the control group, almost all subjects were entirely unaware of tuberculosis contacts (205 subjects/89.9\%).

Table 1. The Distribution of Research Subjects

\begin{tabular}{|c|c|c|c|c|c|}
\hline \multirow{2}{*}{ No } & \multirow{2}{*}{ Characteristics } & \multicolumn{2}{|c|}{ Case } & \multicolumn{2}{|c|}{ Control } \\
\hline & & $\mathbf{N}$ & $\%$ & $\mathbf{N}$ & $\%$ \\
\hline \multirow[t]{3}{*}{1.} & Gender & & & & \\
\hline & Male & 50 & 29.1 & 122 & 70.9 \\
\hline & Female & 26 & 19.7 & 106 & 80.3 \\
\hline \multirow[t]{3}{*}{2.} & Education & & & & \\
\hline & Low & 43 & 28.7 & 107 & 71.3 \\
\hline & High & 33 & 21.4 & 121 & 78.6 \\
\hline \multirow[t]{3}{*}{3.} & Occupation & & & & \\
\hline & Working at house & 13 & 19.4 & 54 & 80.6 \\
\hline & Working outside the house & 63 & 26.6 & 174 & 73.4 \\
\hline \multirow[t]{3}{*}{4.} & Marital Status & & & & \\
\hline & Unmarried & 11 & 21.6 & 40 & 78.4 \\
\hline & Married & 65 & 25.7 & 188 & $74 \cdot 3$ \\
\hline \multirow[t]{3}{*}{5.} & Smoking & & & & \\
\hline & Smoking & 52 & 36.4 & 91 & 63.6 \\
\hline & Not smoking & 24 & 14.9 & 137 & 85.1 \\
\hline \multirow[t]{3}{*}{6.} & Alcohol & & & & \\
\hline & Alcohol & 22 & 40.0 & 33 & 60.0 \\
\hline & No Alcohol & 54 & 21.7 & 195 & 78.3 \\
\hline \multirow[t]{3}{*}{7.} & Contact & & & & \\
\hline & Contact & 18 & 43.9 & 23 & 56.1 \\
\hline & No Contact & 58 & 22.1 & 205 & 77.9 \\
\hline
\end{tabular}

\section{Pathway Analysis}

The results of the study were analyzed using STATA 13. The steps of pathway analysis were model specifications, model identification, parameter estimation and model respesification. The number of measured variables was 8, endogenous variables (4), and exogenous variables (4). So, the degree of freedom (df) was 20. Then, it can be concluded that df was over identified which means that the path analysis can be done. 
Journal of Epidemiology and Public Health (2017), 2(3): 255-266

https://doi.org/10.26911/jepublichealth.2017.02.03.07

Support from drug taking advisor $(\mathrm{b}=$ $2.5 ; 95 \% \mathrm{CI}=1.84$ to $3.06 ; \mathrm{p}=0.001$ ) improved the drug taking adherence.

High family income decreased depression $(\mathrm{b}=-1.1 ; 95 \% \mathrm{CI}=-2.04$ to $0.23 ; \mathrm{p}=0.014$ ).

Drug side effect increased depression $(\mathrm{b}=0.65 ; 95 \% \mathrm{CI}=-0.14$ to $1.13 ; \mathrm{p}=0.055)$.

Aged $\geq 40$ years increased the likelyhood of comorbidity $(\mathrm{b}=0.87 ; 95 \% \mathrm{CI}=$ 0.12 to $1.61 ; \mathrm{p}=0.022$ ).

\section{DISCUSSION}

\section{The association between drug taking adherence and MDR-TB}

The result of this study showed that drugtaking adherence decreased the risk of MDR-TB. This study is supported by Cuevas and Pe (2015), it is showed that patients who had low adherence during treatment would increase the risk of MDRTB by 2 times compared to the patients with high adherence to tuberculosis. The mechanism of MDR-TB occurrence is associated to drug failure in affecting the germs, or germs that do not absorb OAT. Bhunia et al. (2015) explains that the behavioral changing from sensitive to resistant due to lack of treatment usually occurs within a few weeks after the start of treatment with different time of the occurrence of resistance in each individual. Patients' obedience in the treatment greatly affects the success of treatment. The result of this study showed that MDR-TB is more prevalent in subjects of non-adherence to treatment than the subjects who are obedient in doing the treatment. Fagundez et al. (2016) explained that irregular followup of tuberculosis causes a person to have 3 times higher risk for MDR-TB than a patient who conducts the follow up routinely, this is in line with a study by Aderita Aderita et al. (2016) which showed that low-compliance tuberculosis patients had 4 times higher risk for MDR-TB.

\section{The association between comorbi- dity and MDR-TB}

The result of this study showed that comorbidity increase the risk of MDR-TB. Diabetes mellitus (DM) is one of the most common comorbidities in tuberculosis cases (Magee et al., 2013). Navarro et al. (2015) explains that type 2 of DM comorbidities in TB cases leads to a decrease in the immune system, which is associated with poor blood sugar control, leading to impaired phagocytosis, chemotaxis, reactive oxygen species (ROS), and $\mathrm{Th}_{17}$ cell function. In addition, Baghaei et al. (2015) stated that the immune response disorders in TB patients with DM may increase the risk of resistant strains of infection, and it leads to MDR-TB.

Based on the research by Mohd et al. (2015), it is showed that assessing the conversion in TB patients with DM after two to three months of TB therapy had 7 times higher risk for no convention. The possibility of more severe infections, more mycobacterial charges, longer convention times, and longer treatment in TB patients with DM are more likely to be resistant to TB. According to Viswanathan et al. (2014), BTA smear in patients with DM remained positive in the second month of treatment, it is an important risk factor for the transmission of resistance.

WHO describes the association of TB and DM is that the patients have 4 times higher risk of death, plasma OAT concentrations lower than non-DM patients, therefore, it leads to the risk of treatment failure (OAT resistance) and poor glycemic control which can interfere the DM treatment through drug interactions, and the disruption of certain OAT activities (Ministry of Health, 2015). 
3. The association between depression and MDR-TB through drug taking adherence

The result of this study showed that depression increase the risk of MDR-TB. Depression can affect the disobedience of treatment, the depression can increase the risk of morbidity and mortality as a result of TB disease (Duko et al., 2015). Early diagnosis of TB disease becomes one of the stressors that cause psychological disorders especially depression and become one of the factors that can affect the treatment process (Pachi et al., 2013). Depression experienced by tuberculosis sufferers often causes the obstruction in the treatment process. The causes of increased depression are associated with misconceptions about disease and long treatment (Peddireddy, 2016). Depression that occurs will affect the decrease of body resistance to infection and affect the adherence of tuberculosis patients in doing tuberculosis treatment process, therefore, it slows the healing process and increases the risk of MDR-TB (Theron et al., 2015).

\section{The association betwen drug taking advisor and MDR-TB through adherence}

DOTS program is used as an effort to control tuberculosis to ensure short-term treatment of patients can be resolved properly, in addition, DOTS program can affect the drug-taking adherence (Ministry of Health, 2014). One of the DOTS components is the OAT treatment with direct supervision/DSC (Vijay et al., 2010). Based on the research by Septia et al. (2013) it can be seen that big support from DSC has an effect on the enhancement of adherence. He (2016) explained that motivation and support from DSC can help in increasing the willingness of tuberculosis patients to recover by doing the treatment regularly until it is done.
Routine Follow-up is necessary to maintain the regularity in taking antituberculosis drugs, it is necessary for DSC to always monitor the treatment of tuberculosis patients (Akshata and Chakrabarthy, 2016), besides that, if tuberculosis patients do the treatment regularly, it will reduce the risk of increasing the disease and prevent the transmission of tuberculosis disease to others (Thi et al., 2015).

\section{The association between drug side effect and MDR-TB through drug taking adherence}

The result of this study showed that DSE increase the risk of MDR-TB. According to Zhang et al. (2016), DSE affects medication adherence and impacts on drop out treatment. Woimo et al. (2017) stated that the lower the side effects that appear the higher the medication adherence. In addition, the treatment period that takes a long time and it leads to DSE, therefore, it causes the patient to stop taking the medicine (Gao et al., 2016).

\section{The association between family income and MDR-TB through depression and adherence}

The result of this study showed that family income decrease the risk of MDR-TB through depression and adherence. According to a study by Liu et al. (2015), it is stated that social economy becomes one of the factors that influence the tuberculosis. Another problem that occurs in the case of tuberculosis other than death is the fundamental problem which is economic problems both from government and individuals, therefore the decrease of productivity in tuberculosis sufferer becomes a problem that need to be solved.

Financial life is highly dependent on someone's ability to work. If she/he is no longer productive and she/he has physical weakness caused by tuberculosis disease, it can lead to decreased work productivity 
Journal of Epidemiology and Public Health (2017), 2(3): 255-266

https://doi.org/10.26911/jepublichealth.2017.02.03.07

(Ambaw et al., 2015). Depression in tuberculosis patients is also associated with many factors, such as age, sex, socioeconomic status, changes in social relations and stigmatization of tuberculosis (Koyanagi et al., 2017). Economic problems, stigma and social support become one of the factors that affect the depression in patients with tuberculosis (Duko et al., 2015). Thomas et al. (2016) stated that risk factors that affect the development of various psychiatric disorders is related to low socioeconomic status. This in accordance with the results of this study which indicates that family income increases the risk of MDR-TB through depression.

\section{The association between drug side effect and MDR-TB through depression and adherence}

The result of this study showed that DSE increase the risk of MDR-TB through depression and adherence. WHO defines ADRs as response to a drug, unintentionally or undesirably and occurs at doses that commonly used for the prevention, diagnosis or treatment of disease (Koyanagi et al., 2017). The high prevalence of psychiatric problems, especially depression as well as the presence of psychological reactions related to the perception of disease shows that psychological complications have a side effect of tuberculosis treatment (Farazi et al., 2014). One of the side effects obtained by tuberculosis treatment is the physical effects that cause the disruption of the work and or may affect the social role of the sufferer (Sulehri et al., 2012).

Koyanagi et al. (2017) explains that the factors that may affect the depression in patients with tuberculosis are age $\geq 32$ years old, male gender, tuberculosis diagnosis, drug side effects, low socioeconomic and comorbidities. Marra et al. (2014), explained that the decrease in the quality of life in patients with tuberculosis due to depression caused by many related aspects such as the existence of long-term therapy, social stigma associated with tuberculosis, lack of patient knowledge about disease, tuberculosis treatment process, and adverse reactions (drug side effects) in most tuberculosis patients.

\section{The association between age and MDR-TB through comordibity}

The result of this study showed that age increase the risk of MDR-TB through comordibityPhysiological function of the body will decrease at older age $(\geq 60$ years old) and along with the enhancement of age can lead to ateroklerosis and macro angiopathy disorder that affect the decrease of blood circulation so that it can lead to the occurrence of diseases such as diabetes mellitus and hypertension (Young et al., 2009). In some studies, it has been found that there is a significant relationship between age and OAT resistance with higher proportion of MDR-TB among the 45-64 years old group, in addition, the DM comorbidities in older TB patients increases the risk of MDR-TB, because in the elderly, the decrease in the immune system leads to physical inability to fight TB bacilli thus increasing the risk of MDR-TB (Wahyuni et al., 2016). Similar to Tao et al. (2017) which stated that a person with diabetes and HIV/AIDS aged $\geq 45$ years has 2 times higher risk of having MDR-TB due to a low immune system and decreased body function. Aibana et al. (2017) explains that the older the person, the lower the immunity in the body, and the older age groups are more exposed to other risk factors such as alcohol, cigarette smoke and infectious diseases.

Based on the result of this study, it can be concluded that the risk of MDR-TB decrease by the enhancement of drugtaking adherence, the support from DSC 
and family income. The risk of MDR-TB is increased by the enhancement of comordibity, depression, DSE and age.

\section{REFERENCE}

Abubakar I, Zignol M, Falzon D, Raviglione M, Ditiu L, Masham S, Adetifa I et al. (2013). Tuberculosis 2013: 5 Drugresistant tuberculosis: Time For Visionary Political Leadership. Lancet Infect Dis. 13: 529-539.

Aderita NI, Murti B, Suryani N (2016). Risk Factors Affecting Multi-Drug Resistant Tuberculosis in Surakarta and Wonogiri, Central Java, Indonesia. Journal of Health Promotion and Behavior, 1: 88-101.

Aibana O, Bachmaha M, Krasiuk V, Rybak N, Flanigan TP, Petrenko V, Murray MB (2017). Risk Factors for Poor Multidrug-Resistant Tuberculosis Treatment Outcomes in Kyiv. BMC Infectious Diseases, 17: 1-7.

Akshata JS, Chakrabarthy A (2016). Management of Multidrug Resistant Tuberculosis (MDR-TB) - Monitoring is the Key to Successful Outcome. Egyptian Journal of Chest Diseases and Tuberculosis, 65(2): 447-450.

Ambaw F, Mayston R, Hanlon C, Alem A (2015). Depression among Patients with Tuberculosis: Determinants, Course and Impact on Pathways to Care and Treatment Outcomes in a Primary Care Setting in Southern Ethiopia-a Study Protocol. BMJ Open, 5: 1-10.

Amita J, Pratima D (2008). Multidrug Resistant to Extensively Drug Resistant Tuberculosis: What is Next? (Special Issue. Emerging and ReEmerging Infections in India). Journal of Biosciences, 33: 605-616.

Atre S (2015). An Urgent Need for Building Technical Capacity for Rapid Diag- nosis of Multidrug-Resistant Tuberculosis (MDR-TB) Among New Cases: a Case Report from Maharashtra, India. Journal of Infection and Public Health, 8(5): 502-505.

Baghaei P, Tabarsi P, Moniri A, Marjani M, Velayati AA (2015). Impact of Diabetes Mellitus on Tuberculosis Drug Resistance in New Cases of Tuberculosis. International Journal of Mycobacteriology, 4: 128.

Bhunia SK., Sarkar M, Banerjee A, Giri B (2015). An Update on Pathogenesis and Management of Tuberculosis with Special Reference to Drug Resistance. Asian Pacific Journal of Tropical Disease, 5(9): 673-686.

Cuevas CD, Pe W (2015). Psychometric Properties of the Eight-Item Morisky Medication Adherence Scale (MMAS8) in a Psychiatric Nate. International Journal of Clinical and Health Psychology, 15: 121-129.

Dinas Kesehatan Provinsi Jawa Tengah (2016). Buku Saku Kesehatan Triwulan 2 tahun 2016. Semarang: Dinas Kesehatan Provinsi Jawa Tengah.

Duko B, Gebeyehu A, Ayano G (2015). Prevalence and Correlates of Depression and Anxiety Among Patients with Tuberculosis at Wolaitasodo University Hospital and Sodo Health Center, Wolaitasodo, South Ethiopia, Cross.BMC Psychiatry, 1-7.

Fagundez G, Freixo HP, Eyene J, CarlosMomo J, Biye L, Esono T, Marcial OM et al. (2016). Treatment Adherence of Tuberculosis Patients Attending Two Reference Units in Equatorial Guinea. PLoS ONE, 11 (9): e0161995.

Falzon D, Jaramillo E, Wares F, Zignol M, Floyd K, Raviglione MC (2013). Universal Access to Care for MultidrugResistant Tuberculosis: an Analysis of Surveillance Data.The Lancet Infecti- 
Journal of Epidemiology and Public Health (2017), 2(3): 255-266

https://doi.org/10.26911/jepublichealth.2017.02.03.07

ous Diseases, 13(8): 690-697.

Farazi A, Sofian M, Jabbariasl M, Keshavarz $S$ (2014). Adverse Reactions to Antituberculosis Drugs in Iranian Tuberculosis Patients. Tuberculosis Research and Treatment, 1-6.

Gao J , Ma Y, Du J, Zhu G, Tan S, Fu Y, Ma $\mathrm{L}$ et al. (2016). Later Emergence of Acquired Drug Resistance and its Effect on Treatment Outcome in Patients Treated with Standard ShortCourse Chemotherapy for Tuberculosis. BMC Pulmonary Medicine, 16:26.

He T (2016). Social Support Received by Multidrug-Resistant Tuberculosis Patients and Related Factors : a Cross-Sectional Study in Zhejiang Province, People's Republic of China. Patient Preference and Adherence, 10: 1063-1070.

Hirpa S, Medhin G, Girma B, Melese M, Mekonen A, Suarez P (2013). Determinants of Multidrug-Resistant Tuberculosis in Patients Who Underwent First-Line Treatment in Addis Ababa: a Case Control Study. BMC Public Health, 13(1): 1.

Kemenkes RI (2014). Strategi Nasional Pengendalian TB. Jakarta: Kemenkes RI.

(2015). Buku Petunjuk Teknis Penemuan Pasien TB-DM di Fasilitas Kesehatan Rujukan. Jakarta: Kemenkes RI.

(2016). InfoDatin-2016-TB. Jakar-

ta: Kemenkes RI.

Koyanagi A, Vancampfort D, Carvalho AF,

DeVylder JE, Haro JM, Pizzo D, Veronese $\mathrm{N}$ et al. (2017). Depression Comorbid with Tuberculosis and its Impact on Health Status: CrossSectional Analysis of CommunityBased Data From 48 Low- and
Middle-Income Countries. BMC Medicine, 15(1): 1-10.

Liu YX, Pang CK, Liu Y, Sun X, Bin, Li XX, Jiang $\mathrm{S}$ et al. (2015). Association Multidrug-Resistant Tuberculosis and Risk Factors in China: Applying Partial Least Squares Path Modeling. PLoS ONE, 10(5): 1-14.

Magee MJ, Bloss E, Shin SS, Contreras C, Huamane HA, Ticona JC, Bayona J et al. (2013). International Journal of Infectious Diseases Clinical Characteristics, Drug Resistance, and Treatment Outcomes among Tuberculosis Patients with Diabetes in Peru. International Journal of Infectious Diseases, 17(6): 404-e412.

Mekonnen F, Tessema B , Moges F, Gelaw A, Eshetie S, Kumera G (2015). Multidrug Resistant Tuberculosis: Prevalence and Risk Factors in Districts of Metema and West Armachiho, Northwest Ethiopia. BMC Infectious Diseases, 2-7.

Mohd N, Azhar S, Kamaludin F (2015). The Risk Factors of Multidrug-Resistant Tuberculosis among Malaysians. International Journal of Mycobacteriology, 5(1): 51-58.

Navarro LM, Fuentes FJ, Zenteno CR (2015). Type 2 Diabetes Mellitus and its Influence in the Development of Multidrug Resistance Tuberculosis in Patients From Southeastern Mexico. Journal of Diabetes and its Complications, 29(1): 77-82.

Pachi A, Bratis D, Moussas G, Tselebis A (2013). Psychiatric Morbidity and Other Factors Affecting Treatment Adherence in Pulmonary Tuberculosis Patients. Tuberculosis Research and Treatment.

Peddireddy V (2016). Quality of Life, Psychological Interventions and Treatment Outcome in Tuberculosis Pa- 
tients: the Indian Scenario Psychological Distress in Tuberculosis. Frontiers in Psichology, 1-9.

Petruccioli E, Chiacchio T, Pepponi I, Vanini V, Urso R, Cuzzi G, Barcellini L et al. (2016).Characterization of The CD4 and CD8 T-Cell Responses to Quantiferon-TB Plus. Journal of Infection, 73(6): 588-597.

Prosser G, Brandenburg J, Reiling N, Barry CE, Wilkinson RJ, Wilkinson KA (2016). The Bacillary and Macrophage Response to Hypoxia in Tuberculosis and the Consequences for $\mathrm{T}$ Cell Antigen Recognition., Microbes and infection, 1-16.

Septia A, Rahmalia S, Sabrian F (2013). Hubungan Dukungan Keluarga dengan Kepatuhan Minum Obat pada Penderita TB Paru. JOM Psikology, 110.

Sulistiyani, Wahjono H, Sabdono A, Khoeri MM, Karyana E (2015). Antimycobacterial Activities from Seagrass Enhalus sp. Associated Bacteria Against Multi Drug Resistance Tuberculosis (MDR TB) Bacteria. Procedia Environmental Sciences, 23:253-259.

Tao N, He X, Zhang X, Liu Y, Yu C, Li H (2017). International Journal of Infectious Diseases Trends and Characteristics of Drug-Resistant Tuberculosis in Rural. International Journal of Infectious Diseases, 65: 8-14.

Theron G,Peter J, Zijenah L, Chanda D, Mangu C, Clowes P, Rachow A et al. (2015). Psychological Distress and its Relationship with Non-Adherence to TB Treatment: a Multicentre Study. BMC Infectious Diseases,13-19.

Thi TH, Nguyen NV, Dinh SN, Nguyen HB, Cobelens F, Thwaites G, Nguyen HT et al. (2015). Challenges in Detection and Treatment of Multidrug Resistant Tuberculosis Patients in Vietnam.
BMC Public Health, 1-10.

Thomas BE, Shanmugam P, Malaisamy M, Ovung S, Suresh C, Subbaraman R, Adinarayanan S (2016). PsychoSocio-Economic Issues Challenging Multidrug Resistant Tuberculosis Patients: a Systematic Review. PLoS ONE, 1-15.

Vijay S, Kumar P, Chauhan LS, Hanumanthappa B, Kizhakkethil UP, Rao SG (2010). Risk Factors Associated with Default among New Smear Positive TB Patients Treated Under DOTS in India. Tuberculosis Research and Treatment, 5(4).

Viswanathan V, Vigneswari A, Selvan K, Satyavani K, Rajeswari R, Kapur A (2014). Journal of Diabetes and its Complications Effect of Diabetes on Treatment Outcome of Smear-Positive Pulmonary tuberculosis-A report from South India. Journal of Diabetes and Its Complications, 28(2): 162165 .

Wahyuni M, Amir Z, Yunita R, Rahardjo W, Abidin A, Malik AR (2016). Pengaruh Merokok Terhadap Konversi Sputum pada Penderita Tuberkulosis Paru Kategori I. J Respir Indo, 36(2): 106112.

WHO (2016a). Global Report Tuberculosis Report 2016. Geneva: WHO Press.

(2016b). World Health Statistics SDG s. Geneva: WHO Press.

(2017). Global Tuberculosis Report 2017. Geneva: WHO Press.

Woimo TT, Yimer WK, Bati T, Gesesew HA (2017). The Prevalence and Factors Associated for Anti-Tuberculosis Treatment Non-Adherence among Pulmonary Tuberculosis Patients in Public Health Care Facilities in South Ethiopia: a Cross-Sectional Study. BMC Public Health, 17(1): 269.

Young F, Critchley JA, Johnstone LK, 
Journal of Epidemiology and Public Health (2017), 2(3): 255-266

https://doi.org/10.26911/jepublichealth.2017.02.03.07

Unwin NC (2009). Globalization And Health aReview of Co-Morbidity Between Infectious and Chronic Disease in Sub Saharan Africa : TB and Diabetes Mellitus, HIV and Metabolic Syndrome, and the Impact of Globali- zation. BMC Public Health, 9: 1-9.

Zhang C, Wang Y, Shi G, Han W, Zhao H, Zhang $\mathrm{H}$ (2016). Determinants of Multidrug-Resistant Tuberculosis in Henan Province China: a Case Control Study. BMC Public Health, 1-8. 